\title{
マイクロビームを用いた昆虫飛翔筋の進化の 過程に関する構造研究
}

\author{
高輝度光科学研究センター利用研究促進部門 岩本裕之, 井上勝晶, 八木直人
}

\begin{abstract}
Hiroyuki IWAMOTO, Katsuaki INOUE and Naoto YAGI: Evolution of Insect Flight Muscle Structure as Studied by Using X-ray Microbeams
\end{abstract}

$\mathrm{X}$-ray diffraction patterns were recorded from the frozen-hydrated myofibrils of insect flight muscle. X-ray microbeams, generated at the high-flux BL40XU beamline of SPring- 8 , were irradiated along the myofibrillar axis so that the diffraction patterns were recorded from single myofibrils (diameter, $2-3 \mu \mathrm{m}$ ). A total of 50 insect species, covering all the major winged insect orders, were examined. The results show that insects with an asynchronous flight muscle operation have giant single-crystal type myofibrils, in which the orientations of the myofilament lattice planes are preserved along their entire length. The functional significance of having such a highly regular structure is discussed.

\section{1. はじめに}

約 3 億 5000 万年前に出現した昆虫は, 現在地球上で最 も種類数の多いという点で最も繁栄した生き物である。 そ して地上で昆虫のいない空間を探すのが困難なくらい, あ らゆる環境に適応して生息している.昆虫は進化の非常 に早い段階でヒトなどの脊椎動物と分岐したもので, 多 くの点で脊椎動物とは非常に違った体のデザインを取り 入れている. 外骨格の採用，ガスを細部まで直接供給する 呼吸様式, 変態などがそれである.しかし非常に似ている のが筋肉の基本構造で，ヒトの骨格筋も昆虫の筋肉も横 紋筋と呼ばれる共通の構造をもつ(図1).細長い横紋筋

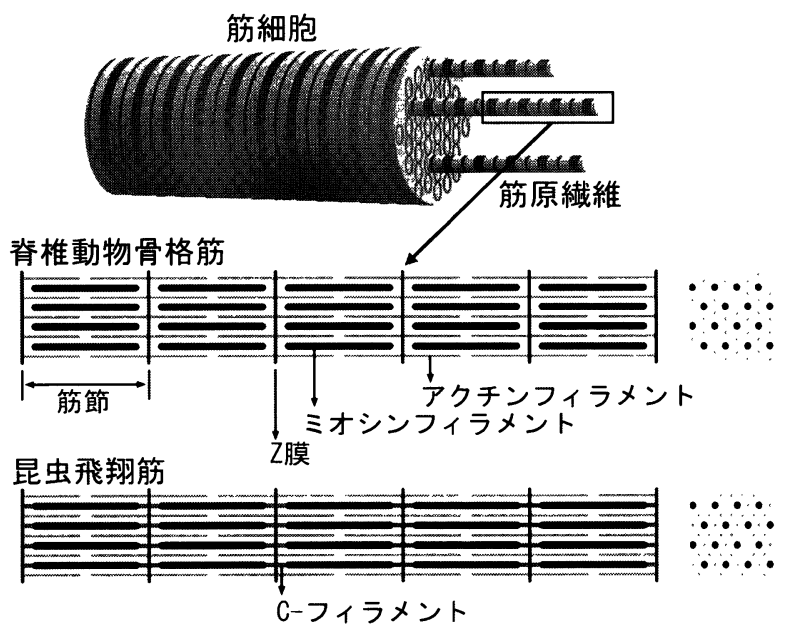

図 1 脊椎動物骨格筋と昆虫飛翔筋の構造. (Structures of vertebrate skeletal muscle and insect flight muscle.)
細胞の中には, 径 1 - $3 \mu \mathrm{m}$ の筋原繊維と呼ばれるものが ぎっしりつまっている.1本の筋原繊維は, 筋節と呼ばれ る収縮機能の最小単位 (長さ $2 \sim 3 \mu \mathrm{m}$ ) が直列に多数つ ながってできている. 光学顕微鏡で観察すると, この筋節 の横並びが横縞のように見えるのがその名の由来である. 横紋筋はクラゲ (腔腸動物) のような非常に原始的な動物 にも見られ，脊椎動物と昆虫が分岐する以前から用いられ ていた非常に古いデザインと考えられる. また細胞内カル シウム濃度を変えて収縮・弛緩を制御する点も共通であ る. 運動神経のインパルスによって筋細胞膜が興奮し, 細 胞内のカルシウム貯蔵部位 (筋小胞体) からカルシウムイ オンが放出される. 弛緩時には筋小胞体のカルシウムポン プによって筋細胞質中からカルシウムイオンが汲み出さ れる.これらの機構も昆虫と脊椎動物で共通である.

\section{2. 横紋筋の $X$ 線回折}

脊椎動物の骨格筋にX 線を照射すると数多くの反射を 生じる.それらは骨格筋細胞内にある各種の収縮タンパク の規則的な配列に由来する.まず, 収縮夕ンパクのアクチ ンとミオシンは, 異なるらせん対称性をもった筋フィラメ ントを形成している.このため回折像中に 2 種のらせん周 期に対応する層状の反射 (層線反射) が生じる (図 $2 A$ ).こ の層線反射の強度分布はらせんのフーリ工变換であるべ ッセル関数で表され，基本的に連続関数である．また，筋 フィラメント同士は六角格子状に配列しているため,これ に由来する強度の高いブラッグ反射が赤道方向に生じる (赤道反射). 

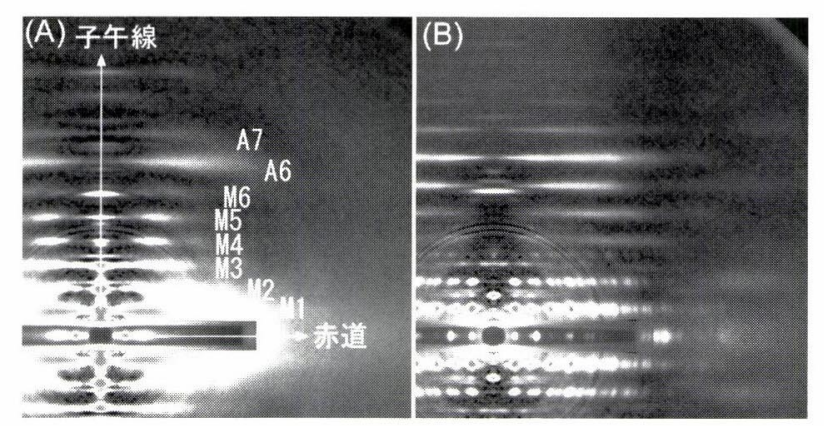

図2 従来法による脊椎動物骨格筋と昆虫飛翔筋の X 線 回折像. (X-ray diffraction patterns from vertebrate skeletal muscle and insect flight muscle, recorded by a conventional method.) (A) ウサギ骨格筋, (B) ガガンボ (ハエ目) の飛翔筋. A， M はそれぞれ アクチン，ミオシンフィラメント由来の層線反射 で, 数字:は次数.

\section{3. 昆虫飛翔筋の特徵}

\section{1 同期型動作と非同期型動作}

昆虫が地球上に繁栄した理由は, 飛翔能力の獲得と体 の小型化であろう. 昆虫は 3 億 5000 万年前, まだ鳥も翼竜 もいなかったころから地球の空を飛び回っていたままた 現在知られる最小の昆虫は体長が $0.18 \mathrm{~mm}$ しかなく, 単 細胞生物のゾウリムシより小さい.これら 2 つ特徴によ り，昆虫はあらゆる生息環境に分布を広げることができ たのであろう。

昆虫が飛ぶのに用いる筋肉，すなわち飛翔筋も横紋筋 であり,その構造も初期には体壁筋と変わらなかったと 考えられる.しかし, 体の小型化に伴って昆虫は大きな問 題に直面し, その解決のため飛翔筋は横紋筋の基本構造 を保ったまま, 機能的にも構造的にも特殊化することに なった。

その問題とは小型化によって高い周波数で羽ばたく必 要が生じたことで, その周波数は小型の蚊の仲間で最高 $1000 \mathrm{~Hz}$ に達する.11 先に述べた筋小胞体からのカルシウ ムイオンの放出・再取り迄みで収縮弛緩を制御する方式 で実現できる羽ばたきの周波数は $100 \mathrm{~Hz}$ が限度と言われ る. 実際，より原始的なバッ夕などはこの方式で羽ばたい ている。このタイプの昆虫の神経インパルスと羽ばたき は完全に同期しているため, 同期型と呼ばれる(図3A).

しかし, $100 \mathrm{~Hz}$ より高い周波数で動作させるには筋小 胞体と, カルシウムポンプにエネルギー (ATP) を供給す るミトコンドリアが非常に発達する必要があり, 肝心の 収縮装置を収容する場所がなくなってしまう。そこで, 蚊 を含む進化した昆虫ではいくつかの戦略の組み合わせで この問題を解決している.

まず, これらの昆虫が飛ぶとき, 飛翔筋は基本的に収縮 したままであり, その収縮状態は羽ばたきより低い頻度

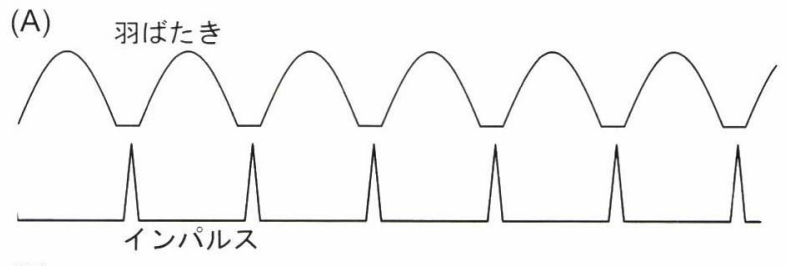

(B)

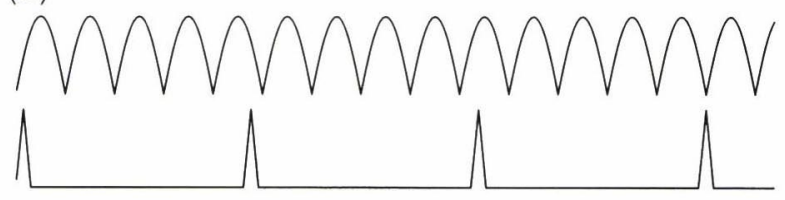

図 3 同期型 (A) と非同期型 (B) 飛翔筋の動作の概念図. (Schematic diagram of action of synchronous and asynchronous flight muscles.) SPring-8ホームペー ジより改変.

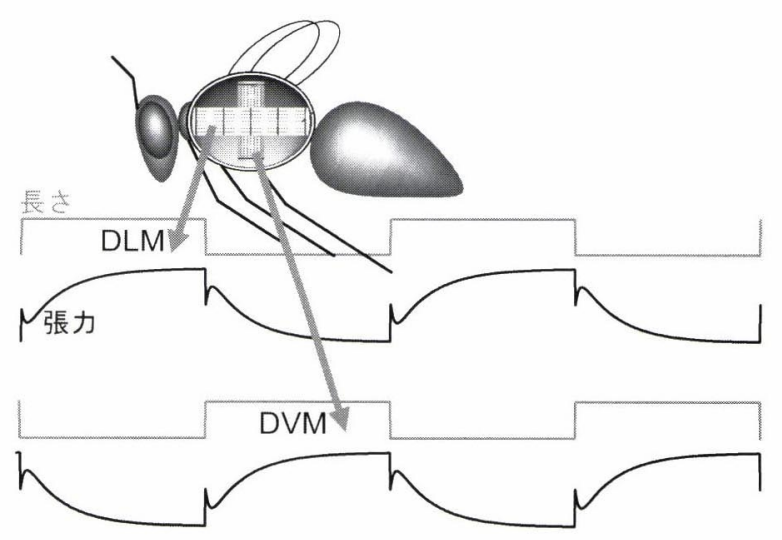

図4 伸長による活性化 (stretch activation, SA) と, 2 種 の拮抗筋の動作概念図. (Schematic diagrams of stretch activation and the two antagonistic muscles.) 長さは上が伸長方向. 実際は矩形波で駆動されて いるわけではない.

の神経インパルスによって維持されていて, 細胞内カルシ ウム濃度も一定である.こうすることで羽ばたきごとにカ ルシウムの放出・汲み上げを行う必要がなくなり, 筋小胞 体も発達せずミトコンドリアも収縮装置にエネルギーを 供給するだけでよい.この方式は羽ばたきと神経インパル スの周波数が一致しないので, 非同期式と呼ばれる（図 3B). 次に, 収縮状態のままで羽ばたくことができるよう に, 飛翔筋は収縮中に自律振動する機能を備えている. 自 律振動には 2 つ機構が関係している.1つは間接飛翔筋 で, 飛翔筋が胸部の外骨格を変形させることで間接的に羽 在動かす方式である. 間接飛翔筋には胸部圭前後方向に走 る dorsal longitudinal muscle (DLM) と, 背腹方向に走る dorsoventral muscle (DVM)の2 種があり,これらは互いに 拮抗筋 (一方が縮むと他方が伸ばされる) である. 2 つ目は stretch activation (SA, 伸長による活性化)で, 筋肉を外か ら引っ張ると遅れて強い力を発生する性質である(図4). 
逆に短縮させると, 遅れて収縮力が減少する. それで拮抗 筋の一方が他方により引き伸ばされると, SAにより発生 した力で相手を引き伸ばし返すが，自身は短縮して力を 失い再び相手により引き伸ばされる。これを繰り返して 羽ばたきを持続することができる。

\subsection{Stretch activation (SA)の分子機構}

SAを可能にする分子機構として「マッチーミスマッチ 仮説」が提唱されている.2)これはミオシン・アクチンの分 子が互いにきわめて精密に配置されているため, ある筋 節長では分子の相互作用 (すなわち力発生) がほとんど起 こらず，それより筋節をわずかに伸長すると相互作用す る分子の数が劇的に増えるというものである.

これを少し詳しく説明すると, ミオシンもアクチンも らせん状のフィラメントを形成しているため, 筋節の中 でミオシン分子があるアクチン分子の近くにあっても，お 互いが相互作用できるように向き合っているとは限らな い.アクチンフィラメントの中で, アクチン分子がうまく ミオシンフィラメントのほうを向いている領域を「ターゲ ットゾーン」という．1本のミオシンフィラメントの周り には6本のアクチンフィラメントがあり, それをミオシン フィラメントのほうからぐるりと回ってながめると, 夕 ーゲットゾーンもらせん状に配置している(図5)。ある 長さでは, どのミオシン分子もターゲットゾーンから離 れているため, アクチンと相互作用できるものはほとん どない(図5A)。しかしこれを約 $2 \mathrm{~nm}$ 引き伸ばすだけで 多くのミオシン分子がターゲットゾーンに入り, 相互作

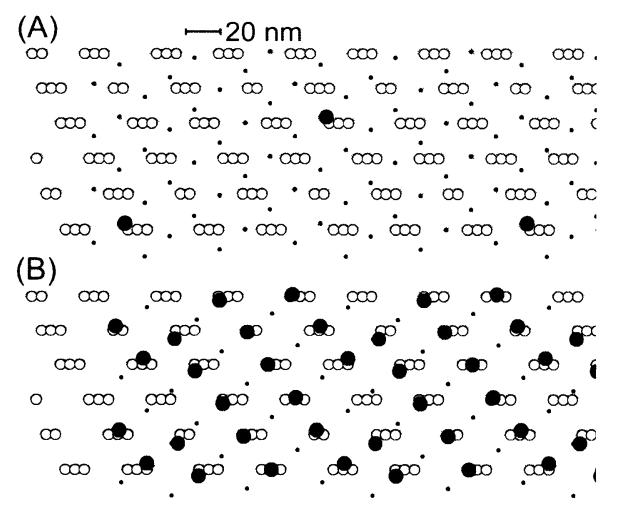

図 5 「マッチーミスマッチ仮説」に基づく stretch activation の分子機構. (Molecular mechanism of stretch activation based on the "match-mismatch hypothesis".) 1 本 のミオシンフィラメントを取り巻く6本のアクチ ンフィラメント(灰色)をミオシン側から眺めたと ころ.ターゲットゾーンにあるアクチン分子を白 丸, ミオシン分子の位置を小さな黒丸, また実際 に相互作用できる位置にあるミオシン分子を大き な黒丸で表す. (A) の長さで相互作用できるものは ほとんどないが，20 nm 伸長すると (B) 多くの分 子が相互作用できるようになる。
用するものが圧倒的に増加する (図 5B)．この「マッチー ミスマッチ仮説」は, 実際に電子顕微鏡下でミオシン分子 がターゲットゾーンに選択的に結合する様子が観察され ること,3) 飛翔筋の長さを変えていくと張力が $3.8 \mathrm{~nm}($ ア クチンフィラメントのらせんピッチ) ごとに周期的に変化 することやから支持されている(ただし反論もある。これ については最後に簡単に述べる).

上の「マッチーミスマッチ仮説」によれば, SAが起こ るためには収縮夕ンパクの配列が三次元空間的に高い規 則性 (つまり結晶性)をもつ必要がある. 結晶の X 線回折 像の特徵はラウエ関数で表現される離散的なブラッグ反 射である. 実際, 昆虫飛翔筋試料として最もよく用いられ てきたタガメ飛翔筋では, 赤道反射だけでなく層線反射 (特に低次の層線) も離散的なブラッグ反射列になること が知られており，その筋節がそれ自身1個のタンパク単結 晶とみなせることがわかっていた. 昆虫飛翔筋の回折像の 例を図2Bに示す，また昆虫飛翔筋にはアクチン・ミオシ ン間の相互の位置関倸を保つのに役立つ特別な構造があ る.それは筋節の境界にあるZ膜 (図1参照) とミオシン フィラメントを結ぶC-フィラメントという短く強固な弾 性タンパクのフィラメントである.このC-フィラメント のため, 昆虫飛翔筋は春椎動物骨格筋のように自由に長さ を変えることはできない，

\section{4. 単一筋原繊維のX $X$ 線回折像}

さて, ここからわれわれの研究の話に入る. 筋肉は古く からX線回折実験の試料として用いられてきた. 実験室の $\mathrm{X}$ 線発生器の時代には筋肉 1 本をまるごと用いるのが普通 で, 第 2 世代放射光施設の時代に入っても単一筋細胞 (径 $100 \sim 200 \mu \mathrm{m})$ が最小であった. 第 3 世代放射光施設の SPring-8が利用可能になったとき, その可能性を追求する ため小角散乱ビームライン BL45XUにおいて筋細胞内の 単一の筋原繊維 (径 $2-3 \mu \mathrm{m}$ ) から回折像の記録を試みた. 試料はマルハナバチの飛翔筋である. 昆虫飛翔筋を選ん だのは, 上記のように高い規則性により強い反射が得られ ると期待したからである. 単離した筋原瀻維は取扱が難し く, 単結晶性のためX線を繊維軸に直角に当てる通常の 方法ではすべての反射が同時に記録できないという困難 が予想された，そこで，筋原瀻維の径以下（径 $2 \mu \mathrm{m}$ )のX 線マイクロビームを作り, 纎維軸に平行に当てることで (エンドオン照射) 筋細胞中の 1 本の筋原繊維を狙い撃ち し，すべての反射を同時記録することにした(図6).この 方法で記録されるものは赤道反射と同等だが, ブラッグ反 射ではなく平面回折格子からの回折像に近い. $\mathrm{X}$ 線の進行 方向のコヒーレンス長は短いので異なる筋節間の干渉は 起こらず, 筋細胞内に並んだ個々の筋節からの独立な回折 像が強度加算されて記録されると考えられる。

単一の筋節のエンドオン回折像に期待されるのは六角 


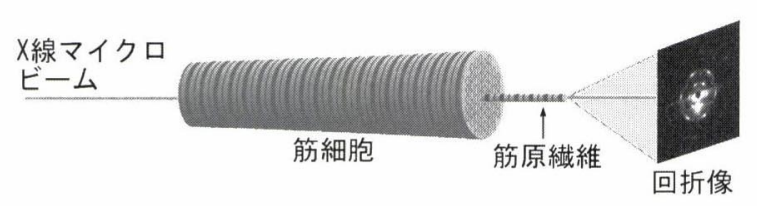

図6 X 線マイクロビームによる単一筋原繊維のエンド オン回折像記録. (End-on diffraction pattern recorded from a single myofibril by using an X-ray microbeam.) SPring-8 ホームページより改変.

(A)

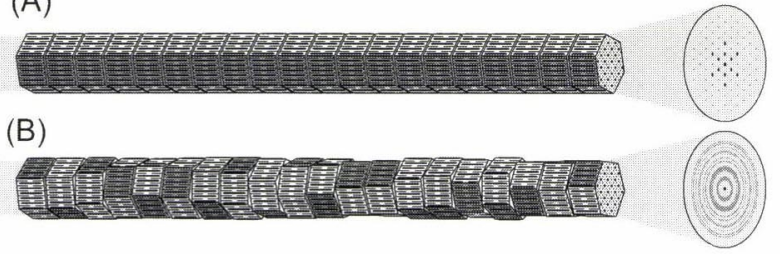

図7 1 本の筋原繊維内の筋節の格子面の配列. (Possible patterns of arrangement of sarcomere lattice planes within a single myofibil.) (A) は全長にわたって 格子面が揃っている場合，（B）は格子面がまった くランダムな場合. 予想される回折像を右の川内 に示す. 文献 7) より改変.

格子状に並んだ一群のスポット反射であるが，筋節が多 数直列に並んだ筋原繊維の場合はいくつかのケースが考 えられる (図7). 図7Aのようにすべての筋節の格子面が 揃っていれば単一六角格子の反射が観察されるはずだが, 筋フィラメントはZ膜により分断されているため, 格子 面は図7Bのようにずれて粉末回折のような同心円の反 射になると予想した，ところが実際に測定すると単一六 角格子の反射が記録され，格子面は図7Aのように筋原繊 維の全長にわたって完全に揃っていることが判明した.5) 筋原繊維の全長が $3 \mathrm{~mm}$ 程度あり, この中には 1000 個も の筋節があることを考えれば，この規則性の高さは驚く べきものである，昆虫飛翔筋では個々の筋節が結晶性で あるだけでなく、筋原繊維全体が 1 個のタンパク巨大単結 晶とみなせる構造をとっているのである。

\section{5. 筋原繊維結晶性の系統進化}

上の測定に用いたマルハナバチは最も進化した昆虫の 1つであったのだが, 次の疑問は筋原繊維の巨大単結晶構 造が進化の過程でどのように生じてきたかということで あった. 巨大単結晶型は, 進化した非同期型の昆虫に限ら れるのだろうか? そこで, 原始的なものから進化した ものまで，できるだけ多くのグループの昆虫から飛翔筋 をとり，マイクロビーム回折法により構造を調べること にした。

上の測定では筋細胞をそのまま常温において測定して 340
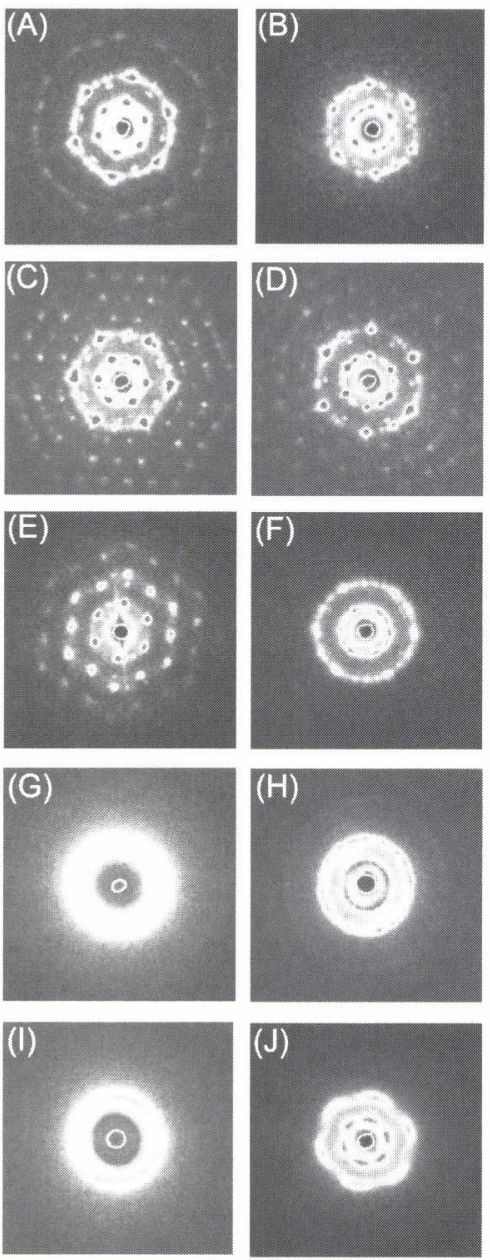

図 8 各種昆虫の急速凍結筋原繊維のエンドオン回折像. (End-on diffraction patterns recorded from quickfrozen myofibrils from various insects.) (A) マル ハナバチ(ハチ目)，(B)フトハチモドキバエ(ハ エ目)，（C）ウリハムシ (甲虫目)，(D) クロカミキ リ (甲虫目), (E) アオクサカメムシ (カメムシ目), (F) ハルゼミ(カメムシ目)，（G）エゾギクキンウ ワバ(チョウ目)，(H) ホシヒメホウジャク（チョ ウ目スズメガ科)，(I) ショウリヨウバッ夕(バッ 夕目), (J)ミヤマカワトンボ(トンボ目). SPring-8 ホームページより改変.

いたが, 試料の状態が不安定で照射損傷を受けやすいとい う問題があった，そこで試料を急速凍結し，そのまま低温 (液体窒素温度)で測定する方法を開発した。国これによっ て試料の安定性が大幅に増すとともに照射損傷にも格段 に強くなり, 高輝度ビームライン BL40XUでのハイスル ープット測定が可能になった。

このようにして, 主要な有翅昆虫のすべての目にわたる 50 種の昆虫から飛翔筋筋原纎維のエンドオン回折像を記 録した.7)代表的なものを図8に示す。八チ八工, 甲虫や カメムシ類の回折像はいずれも明瞭な単一六角格子の特 徵を示し, 巨大単結晶型の筋原繊維をもつことがわかる (図8A E ). 個々の反射もシャープで, 格子面間隔も揃 日本結晶学会誌 第 48 巻 第 5 号 (2006) 

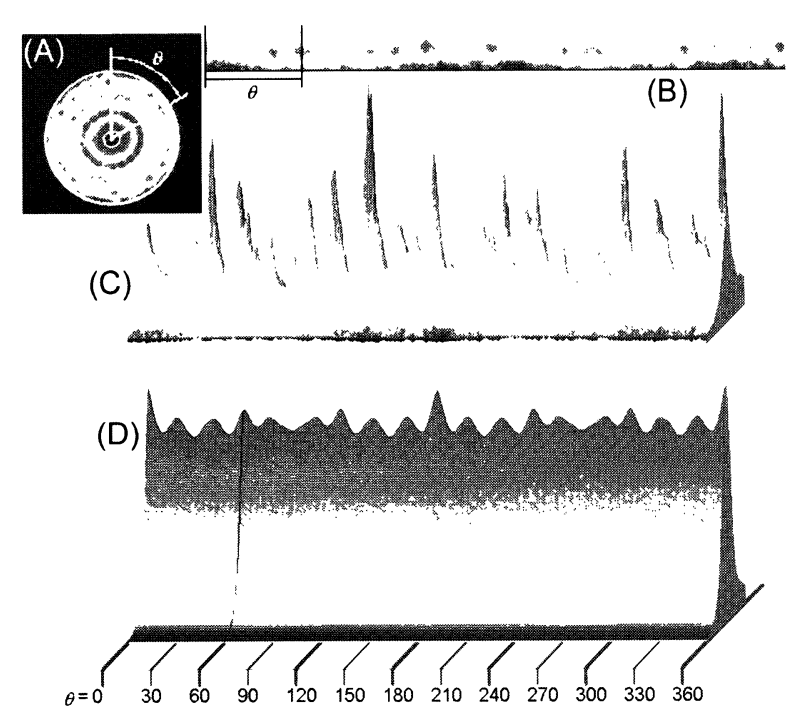

図 9 エンドオン回折像の角度自己相関関数の例 (ハルゼ ミ). (Example of the angular autocorrelation function of an end-on diffraction pattern (cicada).) 回折像 (A)の 2,0 反射領域を直線状に展開したのが $(\mathrm{B})$, その反射強度分布の鳥瞰四 $(\mathrm{C})$ ，角度自己相関関 数の鳥瞰図 (D).ランダムに发射スポットが並ん でいるように見えるが，正確に 60 度ごとの位置に ピークがあり, 少数 (3 個) の単一六角格子のパ夕 ーンが重なっているのがわかる.

っていることがうかがえる.これらの昆虫はいずれも非同 期型の飛翔筋をもつ. それに対して，ガやバッタなどでは 回折像がぼけた同心円状であり，格子が揃っていないうえ 格子面間隔のバラつきも大きいことがわかる(図 8G，I). これらの昆虫は同期型の飛翔筋をもつ.

また筋原繊維構造の長距離規則性を客観的に評価する ため, マイクロビームに対して試料をXY 方向に一定間隔 でスキャンし, 得られた 100 枚以上の回折像すべてを解析 した. その解析項目の 1 つは角度自己相関関数

$$
f(\theta)=\int_{0}^{360} I(x) \cdot I(x+\theta) d x
$$

である.これは回折像の中で最も強度の高い 2,0 反射を含 む散乱角での散乱強度 $I$ を円周に沿って測定し，ある角度 (日) 離れた 2 点の散乱強度の積を全円周に浴って積分した ものである (図9).この関数が 60 度のところにピークを もつとき，ある場所にピークがあればその 60 度先にもピ 一クがある傾向を示していて, 六角格子的特徵と判断さ れる. 多数のピークがランダムにあるように見えても，自 己相関関数の 60 度のところにピークがあれば, 小数の六 角格子の回折像が重なっていることが予測される。また 自己相関関数の 60 度ピークの高さと反射のシャープさ (半値幅の逆数)の間には正の相関が認められた.

このようないくつかのパラメータから総合的に判断した とき，同期型飛翔筋をもつ種であっても規則性の高さに 日本結晶学会誌 第 48 巻 第 5 号 (2006)
関して中間型が存在することが明らかになった，その1つ はトンボ日で, 最も原始的な有翅昆虫と考えられている が，回折像は明瞭な六角格子的特徵を示す (図 8J). また ガの仲間は一般的に格子の規則性が低いが, スズメガ科だ けは回折像が比較的少数の六角格子に由来することを示 し, 反射も比較的シャープである (図8H)，これらの昆虫 はいずれも飛翔に強く依存した生活形態をもっている.

また, セミは典型的な巨大単結晶型昆虫のカメムシ類と 同じ目に属するが飛翔筋は同期型である. セミの飛翔筋筋 原繊維の格子構造規則性はスズメガより高く, まれに単一 六角格子由来の回折像が記録されることもある (図 $8 \mathrm{~F}$ ). さらに通常法の回折実験で, 筋節内の収縮タンパクの結晶 性もカメムシ類と同じように高い(岩本ら, 未発表). 七 ミがいずれ非同期型の昆虫へ進化していく途上にあるの かはわかっていない.

\section{6. 巨大単結晶型筋原繊維の意義}

これまでの話をまとめると, 同期型飛翔筋をもつ昆虫の 筋原繊維の規則性は低いものが多いが，一部には部分的な 規則性を発達させているものもある. 他方, 非同期型飛翔 筋をもつ昆虫の筋原繊維は調べた限りでは例外なく巨大 単結晶型である. 非同期型飛翔筋は進化の途上で異なる種 群に独立に何回も生じたと考えられている. それにもかか わらず，非同期型飛翔筋は結晶性の筋節やC-フィラメン トの存在など, 多くの特徵を共有している.そして今回, 巨大単結晶型という特徵も共有することがわかった. 非同 期型の飛翔筋が巨大単結晶型の構造をもつ意義とは一体 何であろうか?

前に述べた「マッチーミスマッチ仮説」によれば, 非同 期型動作に必要な SAにはアクチン・ミオシン間の厳密 な分子配列が必須である. それらの位置関係を厳密に保つ のに有用な構造がミオシンフィラメントと Z 膜を結ぶ Cフィラメントである. 連続切片の電顕観察で調べられたミ ツバチ飛翔筋の Z膜は C-フィラメントとアクチンフィラ メントを組み込んだ幾何学的精度の高い六角格子で,8)こ れが正確には半ピッチずつ平行移動させながら筋フィラ メントの格子面を隣の筋節に伝達する構造となっている. 今回の結果は, この伝達がわずかの久陷もなく, 1000 個 先の筋節まで驚異的な精度で行われることを示している. また非同期型飛翔筋のもう 1 つの共通点は筋原繊維同士 の横のつながりがなく, 1 本 1 本が力学的に独立している 点である。このような構造では, 途中に不連続な箇所 (例 えば格子面の回転)があればそこに応力が集中して筋原繊 維が破断する可能性もある. 力学特性を均一に保つうえで も巨大単結晶型は有利なのかもしれない.

しかし「マッチーミスマッチ仮説」には異論もある。 Squireによると, 1 本のミオシンフィラメントを考えれば 確かに「マッチーミスマッチ仮説」は成り立つかもしれな 
いが, 周りのミオシンフィラメントの位置はずれている ので発生張力は平均化されてしまうのだという.9 Squire は, 代わりに筋収縮調節タンパク（カルシウムの有無によ り収縮弛緩を調節するタンパク) がSA に関係する可能性 を述べている、その1つがカルシウム受容タンパクのトロ ポニンCであるが，夕ガメは飛翔筋にだけカルシウム結 合能のない分子種を多く発現し，これがカルシウムの代 わりに伸長によって飛翔筋を活性化するという.10)この 分子種のホモログ (相同タンパク)はほかの非同期型昆虫 でも見つかっている.トロポニンCに力学感受性がある かは不明だが，SAに収縮調節タンパクも関倸しているこ とは確からしい.

\section{7. おわりに}

3 億 5000 万年の進化の過程が作り出した昆虫の非同期 型飛翔筋は, 生体システムとして非常に完成度の高いも のである，そして今回，巨大単結晶性という新たな驚きが そこに加えられた. しかし，これによって飛翔筋の進化メ カニズムの謎はかえって梁まったのかもしれない. 系統 の異なる種群に独立に出現したにもかかわらず, 非同期 型飛翔筋は上に述べた多数の特徵を必ずセットにもつ事 実の説明は容易ではない，そしてさらに今回そのリスト に1品目追加したことになる. しかしこの謎を解き明かす ことは, ヒトを含めたあらゆる生物の進化メカニズムの 理解につながる。 なぜなら昆虫もヒトも, 同じ地球上でと もに進化してきた生き物なのだから。

\section{文 献}

1) R. K. Josephson, J. G. Malamud and D. R. Stokes: J. Exp. Biol. 203, 2713 (2000)

2) J. S. Wray: Nature 280, 325 (1979).

3) R. T. Tregear, M. C. Reedy, Y. E. Goldman, K. A. Taylor, H. Winkler, C. Franzini-Armstrong, H. Sasaki, C. Lucaveche and M. K. Reedy: Biophys. J. 86, 3009 (2004).

4) R. H. Abbott and P. E. Cage: J. Muscle Res. Cell Motil. 5, 387 (1984).
5) H. Iwamoto, Y. Nishikawa, J. Wakayama and T. Fujisawa: Biophys. J. 83, 1074 (2002).

6) H. Iwamoto, K. Inoue, T. Fujisawa and N. Yagi: J. Synchrotron Rad. 12, 479 (2005).

7) H. Iwamoto, K. Inoue and N. Yagi: Proc. R. Soc. Lond. B 273, 677 (2006).

8) J. F. Deatherage, N. Cheng and B. Bullard: J. Cell Biol. 108, 1775 (1989).

9) J. M. Squire: J. Muscle Res. Cell Motil. 13, 183 (1992).

10) B. Agianian, U. Krzic, F. Qiu, W. A. Linke, K. Leonard and B. Bullard: EMBO J. 23, 772 (2004).

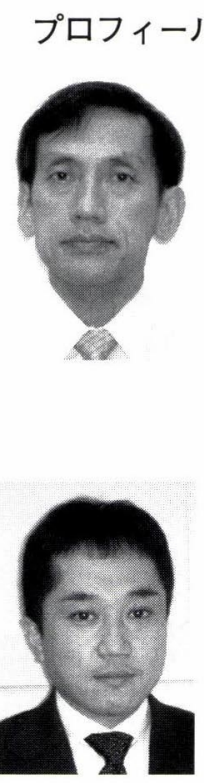

岩本裕之 Hiroyuki IWAMOTO

(財)高輝度光科学研究センター

Japan Synchrotron Radiation Research Institute, SPring-8

干 679-5198 兵庫県佐用郡佐用町光都 1-1-1

1-1-1 Kouto, Sayo-cho, Sayo-gun, Hyogo 679-5198, Japan

e-mail: iwamoto@spring8.or.jp 専門分野：X線繊維回折

井上勝晶 Katsuaki INOUE

(財)高輝度光科学研究センター

Japan Synchrotron Radiation Research Institute, SPring-8

干 679-5198 兵庫県佐用郡佐用町光都 1-1-1

1-1-1 Kouto, Sayo-cho, Sayo-gun, Hyogo 679-5198,

Japan

e-mail: katsuino@spring8.or.jp

専門分野：X線小角散乱

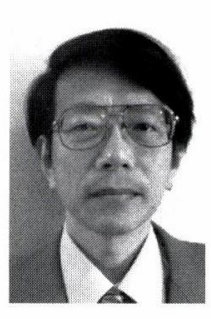

八木直人 Naoto YAGI

(財)高輝度光科学研究センター

Japan Synchrotron Radiation Research Institute, SPring-8

干 679-5198 兵庫県佐用郡佐用町光都 1-1-1

1-1-1 Kouto, Sayo-cho, Sayo-gun, Hyogo 679-5198,

Japan

e-mail: yagi@spring8.or.jp

専門分野：非結晶 X 線回折 